\title{
Anomalously heavy monthly and seasonal precipitation in the Polish Carpathian Mountains and their foreland during the years 1881-2010
}

\author{
Robert Twardosz $^{1}$ - Marta Cebulska ${ }^{2}$ - Adam Walanus ${ }^{3}$ \\ Received: 14 April 2015 / Accepted: 16 July 2015 / Published online: 5 August 2015 \\ (C) The Author(s) 2015. This article is published with open access at Springerlink.com
}

\begin{abstract}
The paper addresses the frequency, amount and geographic coverage of anomalously heavy precipitation in southern Poland in relation to atmospheric circulation at the monthly and seasonal scales between 1881 and 2010. The Carpathian Mountains and their foreland were selected for the study as an area known for its high precipitation totals and frequent precipitation-triggered natural disasters, such as floods and landslides. Records from 18 stations were used to identify anomalously heavy precipitation (AHP) defined for the purposes of the study, as the top quartile $\left(Q_{75} \%\right)$ plus 1.5 times the interquartile gap $(\mathrm{H})$ of the precipitation total $(P \geq$ $\left.Q_{75} \%+1.5 H\right)$. The study found that most cases of AHP were recorded at one single station each. This suggests that, in addition, to the influence of circulation, local factors also play a major role in the formation of particularly heavy precipitation. The greatest absolute anomalously high precipitation totals were recorded in two disparate parts of the study area: (i) its western part exposed to wet air masses from over the Atlantic Ocean brought in by the dominant western circulation in the temperate zone and (ii) elevated parts of its south-eastern part.
\end{abstract}

Robert Twardosz

r.twardosz@uj.edu.pl

Marta Cebulska

marta.cebulska@iigw.pl

Adam Walanus

walanus@geol.agh.edu.pl

1 Department of Climatology, Jagiellonian University, ul. Gronostajowa 7, 30-387 Kraków, Poland

2 Institute of Water Engineering and Water Management, Cracow University of Technology, ul. Warszawska 24, 31-155 Kraków, Poland

3 Faculty of Geology, Geophysics and Environmental Protection, AGH University of Science and Technology, al. A. Mickiewicza 30, 30-059 Kraków, Poland
Two months with AHP (AHP months) occurred over the entire area (18 stations) in May 1940 and 2010. The latter case had both the greatest absolute totals (over $500 \mathrm{~mm}$ ) and relative totals defined as their ratio to the long-term average $(500 \%)$, and it triggered a catastrophic flood in the Upper Vistula basin.

\section{Introduction}

Periodic surpluses or deficits of precipitation may be regarded as dangerous meteorological and hydrological events. If sufficiently large, they can have a significant impact on numerous areas of human activity. Over long spells, they lead to excessive water surpluses or acute droughts. The temperate European climate, mainly influenced by the strong variability of atmospheric circulation, is characterised by the occurrence of long spells of various types of weather, including heavy precipitation, heat waves and cold periods (Twardosz and Kossowska-Cezak 2015). Some studies also suggest a potential role of increased concentrations of carbon dioxide in an increased incidence of extreme precipitation (Palmer and Räisänen 2002; Räisänen 2005). Räisänen (2005) uses ensemble averages to claim that the variability increases slightly in most areas, so that the contrast between the high and low precipitation extremes grows larger with increasing $\mathrm{CO}_{2}$.

The objective of the study was to determine the quantity, frequency, duration and spatial extent of anomalously heavy monthly and seasonal precipitation and the type of circulation favouring the formation of such precipitation in the Polish Carpathian Mountains and their foreland between 1881 and 2010. The project was inspired by the exceptionally wet May of 2010 that caused catastrophic floods and numerous landslides in much of Central Europe (Maciejowski et al. 2011; 
Woźniak 2012, 2013). Christensen and Christensen (2003) suggest that, in future, catastrophic floods of this type are likely to increase in frequency in this part of the continent. Areas prone to exceptionally high rainfall totals, whether daily or monthly, include, in particular, mountains where the effect is augmented by adiabatic cooling of moist air masses in forced ascent. For this reason, the highest precipitation totals, regardless of the time interval, are recorded in mountainous areas of low and medium latitudes, including Poland (for example, the daily total of $300 \mathrm{~mm}$ in Hala Gasienicowa in the Polish Tatra Mountains on 30 June 1973).

Existing studies on precipitation in different areas of southern Poland found no clear-cut trends in the totals (Niedźwiedź et al. 2009; Woźniak 2013). The latest IPCC Report (IPCC 2013), on the other hand, states that the frequency and intensity of heavy precipitation events have likely increased in Europe. In particular, it finds an increase in the frequency of months with anomalously heavy precipitation (Schönwiese et al. 2003; Benestad 2005). Moreover Schönwiese et al. (2003) demonstrated that the increase of extreme wet months is reflected in both a systematic increase in the variance and in the Weibull probability density function parameters. Trömel and Schönwiese (2007) showed that tendencies in the probability of occurrence for extreme values of observational monthly precipitation time series in Germany depend on the season and also vary from region to region.

\section{Sources and data}

The study is based on monthly totals of precipitation recorded at 18 stations, including 14 in the Polish Carpathian Mountains and 4 in their foreland (Table 1, Fig. 1), during the period 1881-2010. The stations were selected to represent low-altitude Carpathian catchment basins.

The monthly precipitation database was built using numerous publications of the Polish weather service, especially its annual hydrographical, meteorological and precipitation reports. The oldest precipitation data, 1881-1890, were found in the study of Hellmann (1906). The period 1895-1912 was completed with data from the Austro-Hungarian Jahrbuch Hydrographischen Zentralbureaus k. k. Ministeriumfüröffentliche Arbeiten. Data after 1982 was found in other available Polish sources (Poland's Main Statistical Office) and on the web service of the European Climate Assessment \& Dataset (ECA\&D) www.eca.knmi.nl. To account for the relocation of some of the stations over the 130year period, the records were verified for homogeneity. Alexandersson's standard normalised homogeneity test (SNHT) was used to test the hypothesis that the monthly totals were homogenous (Alexandersson 1986). Other series of records were tested using the homogenous series from Krakow. In the light of the results, it was concluded that, at the level of significance of 0.05 , there
Table 1 Details of the weather station locations (arranged from west to east)

\begin{tabular}{|c|c|c|c|c|c|}
\hline \multicolumn{2}{|c|}{ Station } & \multirow[t]{2}{*}{ Altitude (m a.s.l.) } & \multicolumn{2}{|c|}{ Geographical coordinates $\left({ }^{\circ},{ }^{\prime}\right)$} & \multirow{2}{*}{$\begin{array}{l}\text { Average totals }(\mathrm{mm}) \pm \\
\text { standard errors }\end{array}$} \\
\hline No & Name & & $\varphi \mathrm{N}$ & $\lambda \mathrm{E}$ & \\
\hline 1 & Wisła & 433 & 4939 & 1851 & $1187 \pm 16$ \\
\hline 2 & Bielsko-Biała & 322 & 4948 & 1900 & $994 \pm 15$ \\
\hline 3 & Żywiec & 354 & 4941 & 1912 & $879 \pm 14$ \\
\hline 4 & Wadowice & 268 & 4952 & 1930 & $748 \pm 11$ \\
\hline 5 & Maków Podh. & 359 & 4943 & 1941 & $908 \pm 14$ \\
\hline 6 & Kraków & 206 & 5003 & 1957 & $681 \pm 10$ \\
\hline 7 & Myślenice & 290 & 4949 & 1957 & $872 \pm 14$ \\
\hline 8 & Rabka & 510 & 4937 & 1958 & $882 \pm 11$ \\
\hline 9 & Zakopane & 844 & 4917 & 1957 & $1131 \pm 16$ \\
\hline 10 & Nowy Sącz & 292 & 4937 & 2041 & $728 \pm 11$ \\
\hline 11 & Krynica & 613 & 4924 & 2057 & $861 \pm 13$ \\
\hline 12 & Tarnów & 225 & 5001 & 2059 & $706 \pm 12$ \\
\hline 13 & Jasło & 240 & 4944 & 2128 & $720 \pm 12$ \\
\hline 14 & Dukla & 351 & 4934 & 2140 & $833 \pm 13$ \\
\hline 15 & Rzeszów & 214 & 5006 & 2201 & $652 \pm 11$ \\
\hline 16 & Sanok & 314 & 4935 & 2211 & $786 \pm 13$ \\
\hline 17 & Wetlina & 700 & 4908 & 2228 & $1075 \pm 18$ \\
\hline 18 & Jarosław & 204 & 5001 & 2241 & $697 \pm 12$ \\
\hline
\end{tabular}




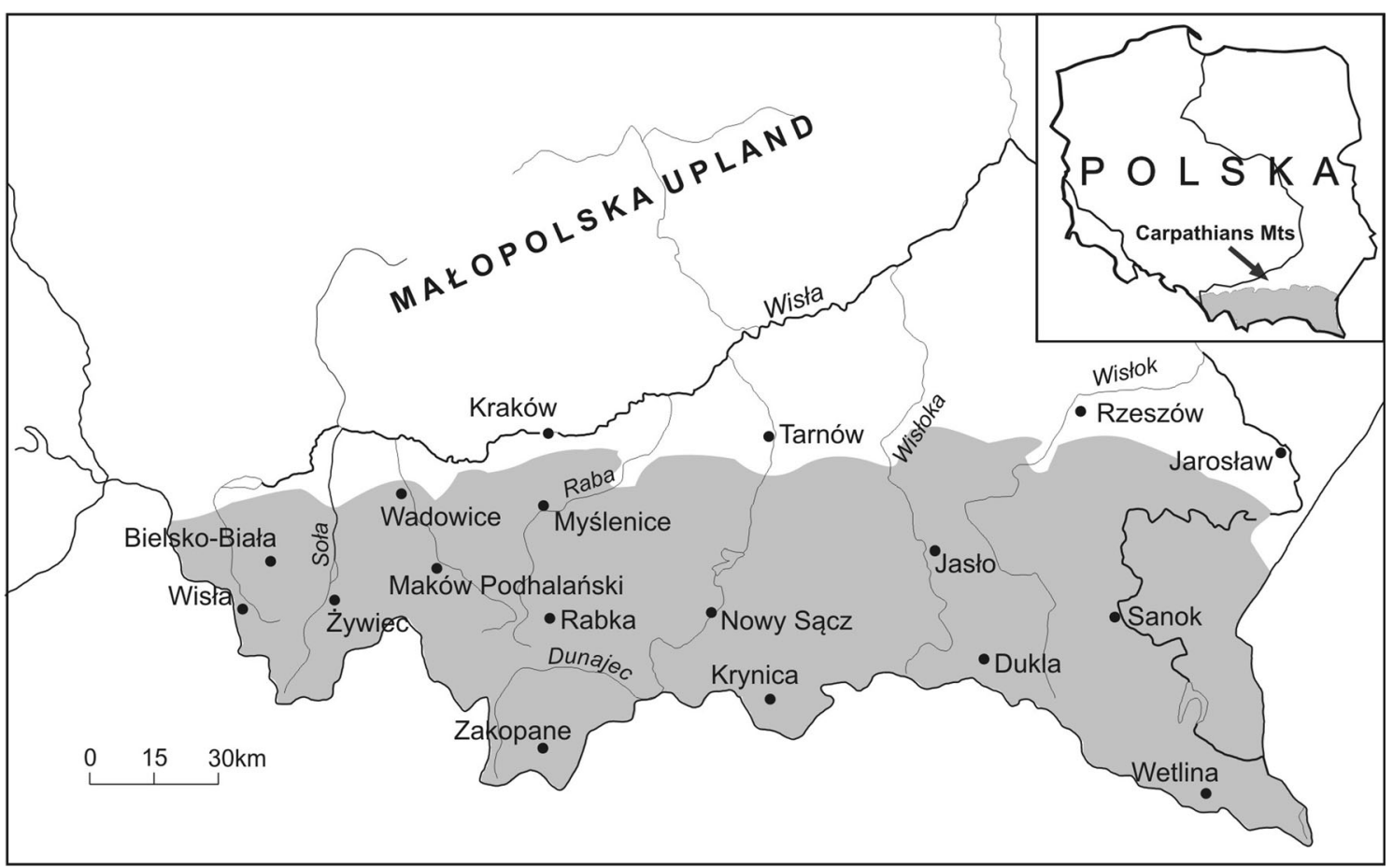

Fig. 1 Location of meteorological stations

were no grounds to reject the hypothesis of homogeneity of the monthly and annual precipitation totals.

None of the monthly precipitation series displays statistical trends of change over the 130-year study period. In this way, they meet the condition of being stationary.

A range of criteria used by climatologists to determine precipitation anomalies, especially the older ones, has been reviewed in numerous climatological studies and reports. One of the more popular methods used to identify anomalous months, seasons and years is the standard deviation, which, in most cases, is applied as a doubled or even tripled value (e.g., Schönwiese et al. 2003). In recent years, a percentile-based method has found its way into studies on daily (e.g., Łupikasza 2010) and monthly precipitation (e.g., Miętus et al. 2005). However, despite the method's growing popularity and even certain deliberate efforts to increase this effect, the fact that the frequency of anomalous values (determined from empirical distribution) in this method is itself a fixed value has ruled it out from a study that is trying to identify such frequencies. Another drawback, from the point of view of this study, is that the method does not utilise the concept of an anomaly as a deviation of a given value from at least a 30year average, as defined by the WMO's International Meteorological Dictionary (International Meteorological 1992).

In their selection of a cut-off criterion, the authors adopted a slightly different approach. Since anomalies, by definition, are rare, the anomalously high totals were identified to fit between the top quartile $\left(Q_{75} \%\right)$ plus $1.5 \times$ the interquartile gap $H\left(H=Q_{75} \%-Q_{25} \%\right)$ and the highest value of the record.
In statistics, values exceeding the interquartile gap are known as "extreme" and those exceeding triple the value of the gap are known as "outliers" (Statistica 2010). Such outlier values may be regarded as either errors of measurement or errors in recording, or, alternatively, as a result of exceptional conditions that caused such values to actually occur (Stedinger et al. 1993). In the case of precipitation, which is characterised by high natural variability of timing, values exceeding the upper quartile plus $1.5 \times$ the interquartile gap will be regarded as non-standard values that deviate considerably from the typical statistical distribution, in other words: anomalous values.

The "interquartile" criterion is defined by the formula:

$$
1.5 *(q(0.75)-q(0.25))+q(0.75)
$$

where $q(p)$ means p-quantile. The factor 1.5 is chosen on the basis of experience in precipitation data analysis as a figure giving extreme precipitation similar to that defined by intuition. The criterion would obviously be profoundly dependent on the shape of the right-hand tail of the probability distribution which describes the data. Since possible theoretical models are different and, moreover, may be modified by assuming different values of the shape parameter, the interquartile criterion would be equivalent to quantiles in the range from 0.9 to 0.997 (Fig. 2). The first value was obtained with a Pareto distribution with a shape parameter $c=2$ and the last with a normal distribution. The interquartile criterion itself does not assume any particular model, as it is based on empirical quartiles. 
Fig. 2 Equivalence of the interquartile criterion to probability (i.e. quantile) according to four distributions. The probability depends on the shape parameter of the given distribution (excluding normal, which has no such parameter). The highest $p=0.9965$ is obtained for normal distribution, and the lowest asymptotic $p=$ 0.951 produces the Pareto as well as the Weibull distributions

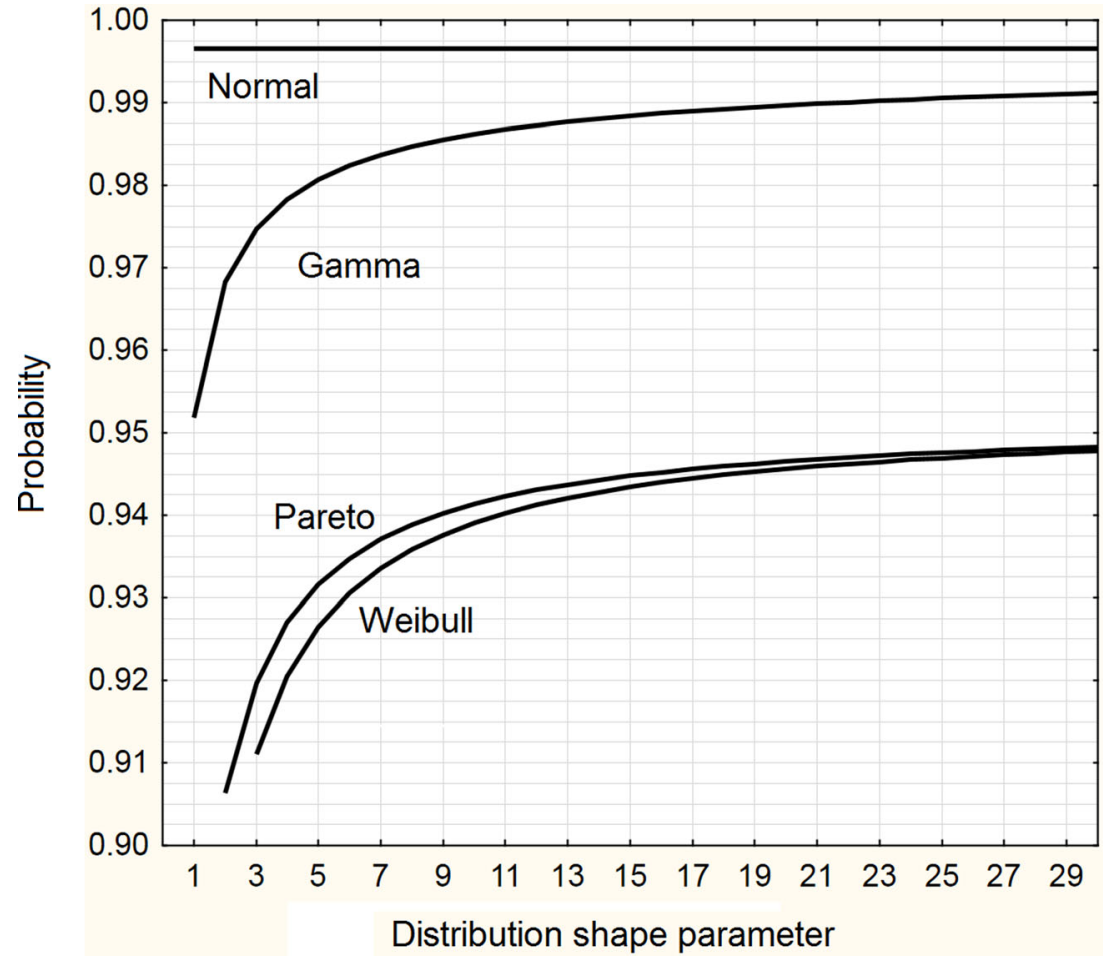

The interquartile criterion was selected for its superior precision in obtaining of the final result when compared to a simpler choice of quantiles Q95 or Q99. Since Q95 and especially Q99 are based on an inherently limited observation samples, the relative errors of their values are large. In contrast, quantiles Q25 and Q75 are free from this deficiency. In a sample of $N=300$, the expected errors of quantiles (calculated according to the binomial distribution) are as follows: Q75$10 \%$, Q95-25\% and Q99-57\%.

In summary, the proposed method of identifying anomalously heavy precipitation has been clearly defined and is simple to use. The number of months with anomalously heavy precipitation matches intuitive expectations, i.e. a range from no such cases (0) to a maximum of nine, which is discussed later on.

This study focused chiefly on months with anomalously heavy precipitation and seasons, but some consideration was also given to years with anomalously heavy precipitation.

In order to identify a dependence of anomalously high monthly precipitation on atmospheric circulation, the authors used the calendar of circulation types in southern Poland devised by T. Niedźwiedź $(1981,2014)$.

\section{General description of the precipitation}

During the study period, the study area received, on average, between ca. $650 \mathrm{~mm}$ of precipitation in the Carpathian foreland (Rzeszów) and nearly $1200 \mathrm{~mm}$ in the Beskid Śląski
Mountains (Wisła) in the westernmost part of the area exposed to wet westerly winds (Table 1). In particular, the highest precipitation totals of the period, at ca. $1700 \mathrm{~mm}$, were recorded in the highest Carpathian range of the Tatras, but stations from this range were not included in the study, as their earliest complete series of records was only in the mid-twentieth century. Precipitation generally increased not just with an increase in altitude along the N-S axis, but also with longitude from east to west (i.e. with a decreasing continental component of the climate). Landform also played a role, as precipitation totals were significantly lower in mid-mountain basins, e.g. Nowy Sącz (Table 1).

There is one general annual precipitation pattern across the area: the values peak in July and bottom out in February or January. This is illustrated by three stations: Kraków, Rabka and Zakopane, representing the N-S altitude profile (Fig. 3). The totals in summer are approximately three times greater than in winter. The average precipitation gradient is $60 \mathrm{~mm}$ per $100 \mathrm{~m}$ of altitude (Niedźwiedź and Obrębska-Starklowa 1991), but the actual values are strongly dependent on the exposure of the slopes and the vertical climate zone.

\section{Frequency of months and seasons with anomalously heavy precipitation and seasons}

During the study period, there were 712 cases of monthly anomalously heavy precipitation (AHP), i.e. $2.5 \%$ of all station-months in the period (12 months $\times 18$ stations $\times$ 
Fig. 3 Annual variation of precipitation at selected stations $(\mathrm{mm})$ and their standard errors

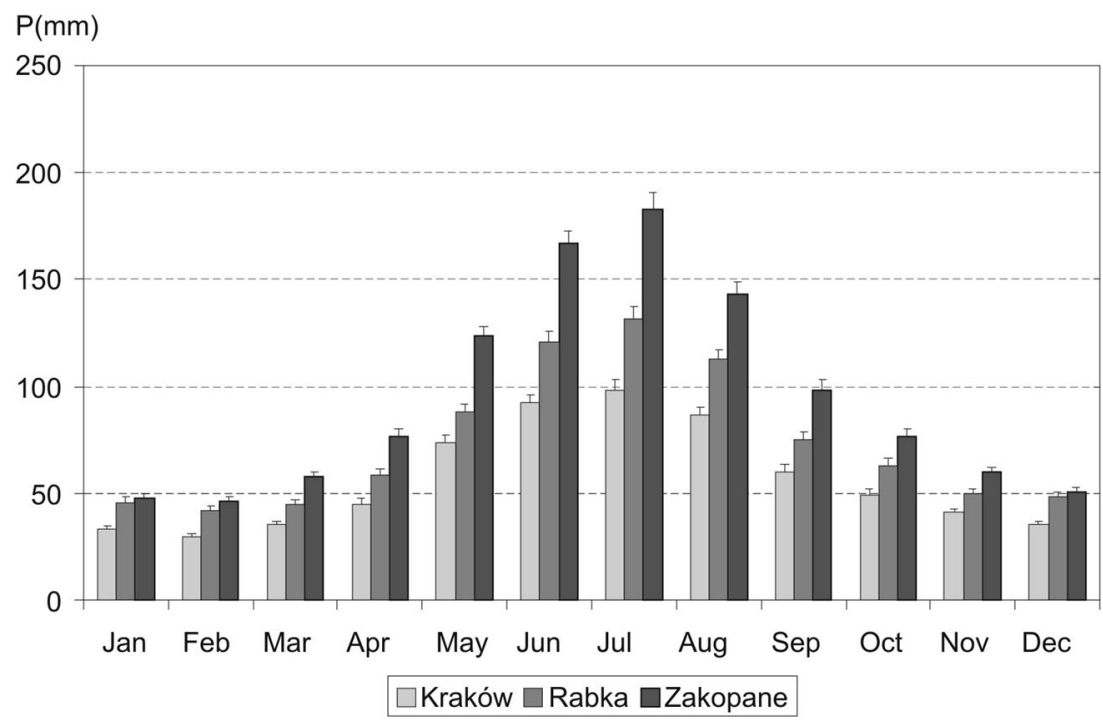

130 years) (Table 2). This translates into nearly 40 months (39.6) with AHP, on average, at each station, which means that, in a given calendar month, there were, on average, 3.3 months with AHP with AHP in a given calendar month per ca. 40 years. The number of AHP months per station varied widely from 29 in Rzeszów to 48 in Nowy Sącz (Fig. 4).

The annual count of AHP months varies widely. Of the 712 AHP months identified (Table 2), the highest numbers were found in May and July at 86 each (i.e. $24 \%$ ) followed by February at 80 (i.e. $11 \%$ ); the lowest was recorded in November at 32 (i.e. $4 \%$ ). To put the seemingly high overall number of AHP months of 712 in the right proportions as an anomaly, one should view it from the point of view of an individual station, which, on average, has to wait 3-5 years to record another AHP month. Certain stations recorded five calendar months without any anomalously high precipitation total. On the other hand, the highest incidence of AHP months at a single station was 9 (July in Jasło).

The 712 AHP months occurred in 212 months $(13.6 \%$ of months), which means that there were years when an AHP month was recorded at more than one station in a single calendar month. May was the no. 1 month of this type with AHP months recorded in 15 years of the period at 18 stations (Table 2). This means that, on average, six stations recorded AHP in the same May. At the other end of the spectrum, the smallest number of stations recording anomalously heavy monthly precipitation was 2 in November (32 AHP months in 15 years, Table 2).
The study also investigated seasons with (AHP seasons) and found 173 such occurrences (Table 3). This gives an average of nearly 10 (9.6) AHP seasons per station or 2.4 AHP seasons per calendar season, i.e. one seasonal AHP per approximately 50 years. The actual distribution varied broadly from 2 at Jarosław to 50 in Bielsko-Biała, Maków Podhalański and Dukla. The most represented season was autumn at 68 (i.e. $39 \%$ ), and the least represented was winter at just 21 (i.e. $12 \%$ ) (Table 3). In other words, during the study period, the average number of AHP seasons varied from ca. 1 in winter to ca. 4 in autumn. All stations recorded a seasonal AHP in autumn, one station had no springtime AHP season, and five stations noted no such seasons in summer and winter. When the overall number of AHP seasons and the number of years with an AHP season are compared, it transpires that the same spring or autumn with AHP was recorded at three to four stations (Table 3), while summers and winters with AHP were smaller in area at just two stations on average.

The study also identified 27 years with AHP (Table 3 ). Five stations recorded three such years, while Wisła and Zakopane recorded none. All such years were recorded by just one station in a given calendar year producing an average of 1-year AHP per station (27 AHP years in 27 years, Fig. 4).

\section{Anomalously high totals}

Anomalously high precipitation totals varied very widely across the study area. In all three intervals studied, i.e. months,
Table 2 The number of cases (1.) of AHP months and the number of months with AHP (2.) (18812010)

\begin{tabular}{llllllllllllll}
\hline & Jan & Feb & March & Apr & May & Jun & July & Aug & Sep & Oct & Nov & Dec & Jan-Dec \\
\hline 1. & 52 & 80 & 44 & 56 & 86 & 67 & 86 & 60 & 66 & 43 & 32 & 40 & 712 \\
2. & 16 & 21 & 15 & 20 & 15 & 24 & 19 & 20 & 19 & 13 & 15 & 17 & 212 \\
\hline
\end{tabular}




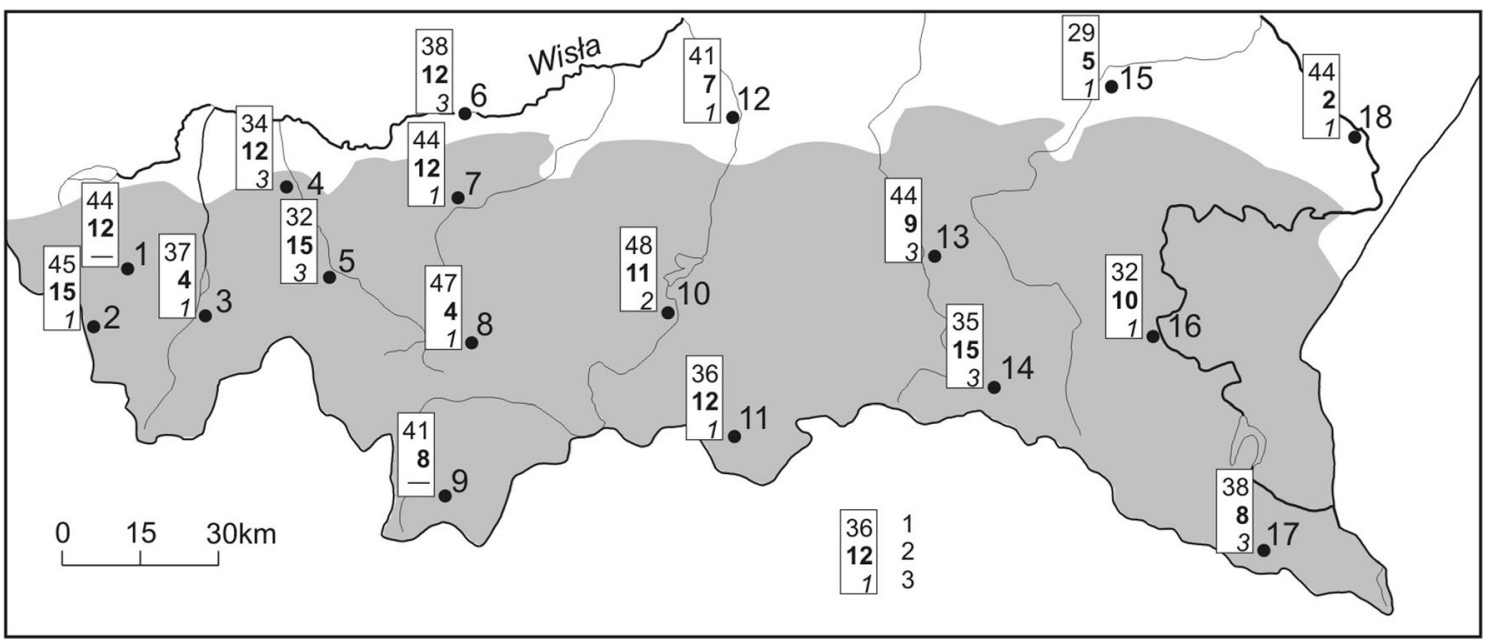

Fig. 4 Number of AHP months (1), AHP seasons (2) and AHP years (3) at particular stations

seasons and years, the highest AHP values were more than twice as high as the lowest AHP (Tables 4 and 5). There was a general spatial pattern where the lowest AHP totals were recorded in the Carpathian foreland and in mid-mountain basins (Nowy Sacz), while the highest values were observed in the westernmost Beskid Ślaski range (Wisła) and in the southeastern Bieszczady range (Wetlina).

The lowest levels of the anomaly were recorded between November and March, while the highest values fell between April and September, which is explained by the annual precipitation cycle. The values ranged from $44.5 \mathrm{~mm}$ in December in Tarnów $\left(1959 ; P_{\max }=82 \mathrm{~mm}\right.$ and $\left.P_{\mathrm{av} .}=37 \mathrm{~mm}\right)$ to $425 \mathrm{~mm}$ in May in Wisła $\left(2010 ; P_{\max }=536 \mathrm{~mm}, P_{\mathrm{av}}\right.$. $111 \mathrm{~mm}$ ) (Table 4).

In relative terms, i.e. the AHP percentage of the average monthly precipitation, the size of the anomaly ranges from an AHP $_{\text {max }}$ of $245 \%$ in January 1976 in Wadowice to $484 \%$ in May 2010 in Wisła (Table 4). The greatest relative anomaly, however, was not an $\mathrm{AHP}_{\max }$, but an AHP in May 2010 at Żywiec at $500 \%$ of the average, when the total was $463 \mathrm{~mm}$ $\left(P_{\mathrm{av} .}=93 \mathrm{~mm}\right)$. This means that the greatest anomaly can exceed the lowest anomaly by more than a factor of 2 .

A comparison of extreme seasonal AHP values reveals that the highest wintertime AHP is lower than the lowest summertime AHP (Table 5).

Table 6 summarises the 10 months with the highest totals in absolute $(\mathrm{mm})$ and relative (\% of average) terms. Over the 130 -year period, 10 months is equivalent to a frequency of

Table 3 The number of cases (1.) of AHP seasons and AHP years and the number of seasons and years with AHP (2.) (1881-2010)

\begin{tabular}{lllllll}
\hline & Winter & Spring & Summer & Autumn & $\Sigma$ & Year \\
\hline 1. & 21 & 51 & 33 & 68 & 173 & 27 \\
2. & 13 & 15 & 17 & 19 & 64 & 27 \\
\hline
\end{tabular}

ca. $5 \%$. July (6) was the most frequent month in this summary and came up mostly in the west of the area where the exposure to the wet westerly winds is the greatest. No such clear-cut pattern was found among the highest relative values, as they occurred in different months and locations.

Among seasonal precipitation totals, the highest values were recorded in summer at western stations and in the highest located stations in the south-eastern part (Table 7). The greatest surplus values over the long-term averages were recorded in all seasons. The maximum reached three times the average (spring of 2010 in Wadowice).

The greatest surplus of years with AHP over the long-term average (177 \%) was recorded in 2010 in Krakow and the lowest (144\%) in the same year at Dukla.

\section{Spatial extent of monthly and seasonal AHP}

Out of the 212 AHP months, $43 \%$ (91) occurred at a single station and $18 \%$ (39) at two stations, which were not always neighbouring stations and were sometimes located very far apart (Table 8 ). In total, nearly $71 \%$ of AHP months (151) were recorded at three or fewer stations. The calendar of AHP months contains all 38 such occurrences recorded at six or more stations (one third of the total stations) (Table 9).

An AHP month was recorded simultaneously at all 18 stations on only two occasions: in May 1940 and May 2010. The latter case involved the highest totals ranging from $179 \mathrm{~mm}$ (263\% of the average) in Rzeszów to $536 \mathrm{~mm}(484 \%)$ at Wisła, and 11 of the stations, mostly located in the western part of the area, recorded their maximum totals in the 130-year period. This record spell of precipitation triggered a flood in southern Poland (Maciejowski et al. 2011). This catastrophic flood claimed more than ten lives and caused unprecedented levels of damage to infrastructure. It also contributed to the activation of numerous landslides, which destroyed hundreds 
Table 4 Extreme values of AHP months and their characteristics

\begin{tabular}{|c|c|c|c|c|c|c|c|c|}
\hline \multirow[t]{2}{*}{ Months } & \multicolumn{4}{|l|}{$\mathrm{AHP}_{\text {min }}$} & \multicolumn{4}{|l|}{$\mathrm{AHP}_{\max }$} \\
\hline & $P(\mathrm{~mm})$ & Year $^{\mathrm{a}}$ & $\%^{\mathrm{b}}$ & Station & $\mathrm{P}(\mathrm{mm})$ & Year $^{\mathrm{a}}$ & $\%^{\mathrm{b}}$ & Station \\
\hline \multirow[t]{2}{*}{ Jan } & 85 & 1976 & 245 & Wadowice & 168 & 1976 & 326 & Krynica \\
\hline & & & & & & & 244 & Wisła \\
\hline Feb & 89 & 1977 & 271 & Tarnów & 191 & 1946 & 303 & Wisła \\
\hline March & 95 & 1887 & 254 & Nowy Sącz & 226 & 2000 & 298 & Wisła \\
\hline Apr & 128 & 2001 & 242 & Wadowice & 233 & 1998 & 320 & Wetlina \\
\hline May & 202 & 1940 & 296 & Rzeszów & 536 & 2010 & 484 & Wisła \\
\hline Jun & 208 & 1884 & 238 & Rzeszów & 478 & 1884 & 321 & Wisła \\
\hline July & 241 & 1913 & 259 & Rzeszów & 521 & 2001 & 377 & Maków Podh. \\
\hline Aug & 188 & 1882 & 228 & Tarnów & 402 & 1925 & 294 & Wisła \\
\hline Sep & 162 & 1904 & 288 & Rzeszów & 359 & 1996 & 354 & Wisła \\
\hline Oct & 155 & 1936 & 332 & Nowy Sącz & 396 & 1974 & 419 & Wetlina \\
\hline Nov & 98 & 1962 & 261 & Nowy Sącz & 270 & 1910 & 329 & Wetlina \\
\hline Dec & 82 & 1959 & 219 & Tarnów & 210 & 1952 & 409 & Bielsko-Biała \\
\hline
\end{tabular}

${ }^{a}$ Year of occurrence

${ }^{\mathrm{b}}$ Percentage of average totals

of buildings, including residential. The former of the two AHP months, May 1940, only resulted in a record monthly precipitation in Rzeszów (202 mm or $296 \%$ ) and Jarosław (206 mm or $292 \%)$. Some stations in the western part recorded higher absolute values (e.g. $281 \mathrm{~mm}$ in Bielsko-Biała), but in relative terms, they were not as extreme. Also, the monthly figures of May 1940 at most of the stations, especially in the western part, were about a half of those recorded in 2010. Nevertheless, the rainfall triggered floods along the entire upper Vistula valley, albeit with less significant effects than those in 2010. Just the year before, in 1939, another May AHP months were recorded at 15 stations when the highest absolute total was observed in Zakopane at $255 \mathrm{~mm}$ and the highest percentage anomaly in Wisła at $223 \%$. Again, this rainfall caused a flood, but of just local extent that mainly affected areas around Krakow.

There was one more AHP month in the warm half of the year that covered nearly all of the area. In total, 17 stations recorded AHP in September 2007 (Rzeszów was the only exception), while seven stations (Żywiec, Wadowice, Krakow, Myslenice, Rabka, Tarnów and Wetlina) noted their maximum rainfall totals of the study period. Additionally, the totals at Żywiec and Wisła (226 mm and $293 \mathrm{~mm}$ ) represented the highest surplus of the average value at $290 \%$.

Two wintertime AHP months, in January 1976 and February 1946, also covered most of the study area. During the former, which covered 16 stations (except Bielsko-Biała and Sanok), 11 stations recorded their study period maximums. Wisła had the highest total, at $168 \mathrm{~mm}(244 \%)$, and Żywiec recorded the greatest surplus, at $351 \%$ $(147 \mathrm{~mm})$. The other AHP months included 15 stations (omitting Nowy Sacz, Krynica and Wetlina), of which five had extremely high totals, including again Wisła with the highest $(191 \mathrm{~mm})$ and Żywiec with the greatest surplus $(314 \%, 121 \mathrm{~mm})$.

The AHP of June 1884 occurred at 13 stations, excluding those in a central-western section and the town of Jarosław. The maximum monthly total was recorded at Wisła, at
Table 5 Extreme values of AHP seasons and AHP years

\begin{tabular}{|c|c|c|c|c|c|c|c|c|}
\hline \multirow[t]{2}{*}{ Seasons and year } & \multicolumn{4}{|l|}{$\mathrm{AHP}_{\text {min }}$} & \multicolumn{4}{|l|}{$\mathrm{AHP}_{\max }$} \\
\hline & $P(\mathrm{~mm})$ & Year $^{\mathrm{a}}$ & $(\%)^{\mathrm{b}}$ & Station & $P(\mathrm{~mm})$ & Year $^{\mathrm{a}}$ & $(\%)^{\mathrm{b}}$ & Station \\
\hline Spring & 268 & 1897 & 174 & Kraków & 662 & 2010 & 247 & Wisła \\
\hline Summer & 486 & 2010 & 175 & Kraków & 813 & 1925 & 182 & Wisła \\
\hline Autumn & 275 & 1936 & 187 & Nowy Sącz & 620 & 1992 & 223 & Wetlina \\
\hline Winter & 193 & $1976 / 77$ & 183 & Wadowice & 395 & $1922 / 23$ & 193 & Wisła \\
\hline Year & 995 & 1966 & 156 & Kraków & 1709 & 1998 & 159 & Wetlina \\
\hline
\end{tabular}

${ }^{\mathrm{a}}$ Year of occurrence

${ }^{\mathrm{b}}$ Percentage of average totals 
Table 6 Months with the heaviest precipitation (1881-2010) (A— by precipitation total (mm) and B — by the amount by which it exceeds the longterm average $(\%))$

\begin{tabular}{|c|c|c|c|c|c|c|c|c|c|}
\hline \multicolumn{5}{|l|}{$\mathrm{A}$} & \multicolumn{5}{|l|}{ B } \\
\hline Lp. & $\mathrm{mm}$ & $(\%)^{\mathrm{a}}$ & Month and year & Station & Lp. & $(\%)^{\mathrm{a}}$ & $\mathrm{mm}$ & Month and year & Station \\
\hline 1 & 535 & 484 & May 2010 & Wisła & 1 & 499 & 463 & May 2010 & Żywiec \\
\hline 2 & 521 & 377 & Jul 2001 & Maków Podh. & 2 & 486 & 516 & May 2010 & Bielsko-Biała \\
\hline 3 & 516 & 486 & May 2010 & Bielsko-Biała & 3 & 484 & 535 & May 2010 & Wisła \\
\hline 4 & 482 & 299 & Jul 1997 & Wisła & 4 & 482 & 418 & May 2010 & Wadowice \\
\hline 5 & 478 & 321 & Jun 1884 & Wisła & 5 & 419 & 396 & Oct 1974 & Wetlina \\
\hline 6 & 463 & 499 & May 2010 & Żywiec & 6 & 409 & 210 & Dec 1952 & Bielsko-Biała \\
\hline 7 & 439 & 240 & Jul 2001 & Zakopane & 7 & 402 & 154 & Mar 1946 & Jarosław \\
\hline 8 & 438 & 239 & Jul 1960 & Zakopane & 8 & 399 & 157 & Jan 1954 & Sanok \\
\hline 9 & 437 & 271 & Jul 1960 & Wisła & 9 & 398 & 140 & Jan 1911 & Nowy Sącz \\
\hline 10 & 433 & 269 & Jul 1908 & Wisła & 10 & 393 & 251 & Oct 1939 & Maków Podh. \\
\hline
\end{tabular}

${ }^{\text {a }}$ Percentage of average totals

$478 \mathrm{~mm}$, and also represented the greatest relative anomaly of $321 \%$. Three other AHP months, in February 1977 and April 1898 and 1916, had a similar spatial coverage with 12,13 and 13 stations, respectively. In the two April cases, five or six stations recorded their maximum precipitation totals of the study period. Also, the absolute and relative scales of the anomalies were similar with totals around $200 \mathrm{~mm}$ and surpluses of $380 \%$.

Another noteworthy groups of anomalies were ones recorded at a smaller number of stations, but where most of the stations noted their period maxima. These included October 1974, when six out of eight stations recorded maximum totals and July 2001 with six out of seven following the same pattern.

Certain months with AHP occurred in the form of small, but concentrated clusters of stations. Six such AHP months covered the western part (February 1952, March 1906 and
2000, July 1960, August 1882 and 1985), one the central part (September 1899) and two the eastern part of the study region (June 1948 and July 1980).

There is an interesting summertime pattern of AHP months with at least six stations (Fig. 5). The largest number of June AHP months occurred in the south-eastern part (including three in Sanok and at Wetlina), while only two occurred in the western part. In August, on the other hand, the western part had several AHP months, while the eastern had none.

The highest number of July AHP months occurred in the western and central-northern part, while, in the south-eastern and eastern parts, there were only one or two.

Roughly, a half of all seasons with AHP and years only occurred at a single station (Table 10) (respectively, 28 out of 64 AHP seasons, i.e. $44 \%$, and 6 out of 11 AHP years, i.e. $55 \%$ ), and nearly three quarters of AHP seasons (46, i.e. $72 \%$ ) occurred at three stations or less. There were four

Table 7 Months with the AHP (1881-2010) (A - by precipitation total ( $\mathrm{mm}$ ) and B - by the amount by which it exceeds the long-term average (\%))

\begin{tabular}{|c|c|c|c|c|c|c|c|c|c|c|c|}
\hline \multicolumn{6}{|l|}{ A } & \multicolumn{6}{|l|}{$\mathrm{B}$} \\
\hline Lp. & $\mathrm{mm}$ & $(\%)^{\mathrm{a}}$ & Seasons & Year & Station & Lp. & $(\%)^{\mathrm{a}}$ & $\mathrm{mm}$ & Seasons & Year & Station \\
\hline 1 & 813 & 182 & Summer & 1925 & Wisła & 1 & 278 & 495 & Spring & 2010 & Wadowice \\
\hline 2 & 801 & 197 & Summer & 1968 & Bielsko-Biała & 2 & 277 & 550 & Spring & 2010 & Żywiec \\
\hline 3 & 778 & 192 & Summer & 1960 & Bielsko-Biała & 3 & 269 & 617 & Spring & 2010 & Bielsko-Biała \\
\hline 4 & 775 & 201 & Summer & 1913 & Wetlina & 4 & 260 & 377 & Winter & $(1910 / 11)$ & Zakopane \\
\hline 5 & 749 & 200 & Summer & 2001 & Maków Podh. & 5 & 259 & 397 & Autumn & 1992 & Jarosław \\
\hline 6 & 714 & 224 & Summer & 1893 & Sanok & 6 & 247 & 474 & Autumn & 1931 & Maków Podh. \\
\hline 7 & 714 & 245 & Summer & 1893 & Jasło & 7 & 247 & 662 & Spring & 2010 & Wisła \\
\hline 8 & 712 & 185 & Summer & 1906 & Wetlina & 8 & 245 & 714 & Summer & 1893 & Jasło \\
\hline 9 & 708 & 189 & Summer & 1934 & Maków Podh. & 9 & 239 & 694 & Summer & 1913 & Jasło \\
\hline 10 & 694 & 239 & Summer & 1913 & Jasło & 10 & 239 & 519 & Autumn & 1930 & Bielsko-Biała \\
\hline
\end{tabular}

${ }^{\text {a }}$ Percentage of average totals 
Table 8 Number of AHP months (2) recorded at the same time in station number ranges (1)

Number of stations

\begin{tabular}{|c|c|c|c|c|c|c|c|c|c|c|c|c|c|c|c|c|c|c|c|}
\hline 1. & 1 & 2 & 3 & 4 & 5 & 6 & 7 & 8 & 9 & 10 & 11 & 12 & 13 & 14 & 15 & 16 & 17 & 18 & $\Sigma$ \\
\hline 2. & 91 & 39 & 20 & 7 & 15 & 8 & 6 & 5 & 4 & 2 & 3 & 1 & 3 & - & 2 & 1 & 1 & 2 & 212 \\
\hline
\end{tabular}

AHP seasons that covered six or more stations, i.e. the springs of 2010 (12 stations) and 1919 (6) and autumns of 1931 and
2007 (11 each). The single such annual period was 2010 with ten stations (Table 10).
Table 9 Calendar of AHP months recorded at least six stations

\begin{tabular}{|c|c|c|c|}
\hline Year & Months & No of station & Stations (numbers as in Table 1) \\
\hline 1882 & Aug & 6 & $3,6,7,9,10,12$ \\
\hline 1884 & Jun & 13 & $1,2,3,7,8,9,10,11,13,14,15,16,17$ \\
\hline 1894 & Jun & 6 & $1,3,8,16,17,18$ \\
\hline 1898 & Apr & 13 & $3,5,6,7,8,9,10,11,12,13,14,16,18$ \\
\hline 1899 & Sep & 6 & $6,8,9,10,11,12$ \\
\hline 1906 & Mar & 6 & $3,4,5,6,8,9$ \\
\hline 1908 & Jul & 6 & $1,2,5,6,12,13$ \\
\hline 1913 & Aug & 6 & $2,10,11,13,14,17$ \\
\hline 1916 & Apr & 13 & $1,3,5,6,7,8,9,12,13,14,15,16,18$ \\
\hline 1919 & May & 6 & $2,6,7,10,13,14$ \\
\hline 1931 & Sep & 11 & $1,2,3,5,7,8,9,10,11,12,14$ \\
\hline 1934 & Jul & 7 & $5,7,8,9,10,12,13$ \\
\hline 1939 & May & 15 & $1,2,3,4,7,8,9,11,12,13,14,15,16,17,18$ \\
\hline 1939 & Oct & 11 & $2,3,4,5,8,12,13,15,16,17,18$ \\
\hline 1940 & May & 18 & $1,2,3,4,5,6,7,8,9,10,11,12,13,14,15,16,17,18$ \\
\hline 1946 & Feb & 15 & $1,2,3,4,5,6,7,8,9,12,13,14,15,16,18$ \\
\hline 1947 & Nov & 9 & $1,2,8,9,10,11,13,14,15$ \\
\hline 1948 & Jun & 7 & $8,9,12,13,14,16,17$ \\
\hline 1952 & Feb & 10 & $2,3,4,5,6,9,10,11,7,8$ \\
\hline 1954 & Dec & 10 & $1,2,3,4,6,8,10,11,12,14$ \\
\hline 1960 & Jul & 11 & $1,2,3,4,5,6,7,8,9,10,12$ \\
\hline 1966 & Feb & 9 & $5,6,7,8,10,11,12,14,18$ \\
\hline 1970 & Jul & 7 & $1,3,4,5,7,12,13$ \\
\hline 1972 & Aug & 7 & $1,2,4,5,8,9,13$ \\
\hline 1974 & Oct & 8 & $3,10,12,13,14,15,17,18$ \\
\hline 1976 & Jan & 16 & $1,3,4,5,6,7,8,9,10,11,12,13,14,15,17,18$ \\
\hline 1977 & Feb & 12 & $1,2,3,4,5,6,7,12,14,15,17,18$ \\
\hline 1980 & Jul & 6 & $13,14,15,16,17,18$ \\
\hline 1982 & Dec & 8 & $4,6,9,10,13,14,15,16$ \\
\hline 1985 & Aug & 9 & $1,2,3,4,5,6,7,9,11$ \\
\hline 1996 & Sep & 8 & $1,5,6,7,8,9,14,16$ \\
\hline 1997 & Jul & 8 & $1,2,3,4,5,6,7,10$ \\
\hline 2000 & Mar & 8 & $1,2,3,4,5,7,8,9$ \\
\hline 2001 & Jul & 7 & $4,5,8,9,10,11,14$ \\
\hline 2004 & Feb & 7 & $4,7,8,12,14,15,18$ \\
\hline 2007 & Sep & 17 & $1,2,3,4,5,6,7,8,9,10,11,12,13,14,16,17,18$ \\
\hline 2009 & Mar & 9 & $1,2,3,4,8,13,14,15,18$ \\
\hline 2010 & May & 18 & $1,2,3,4,5,6,7,8,9,10,11,12,13,14,15,16,17,18$ \\
\hline
\end{tabular}

Maximum values in italics in 130 years 

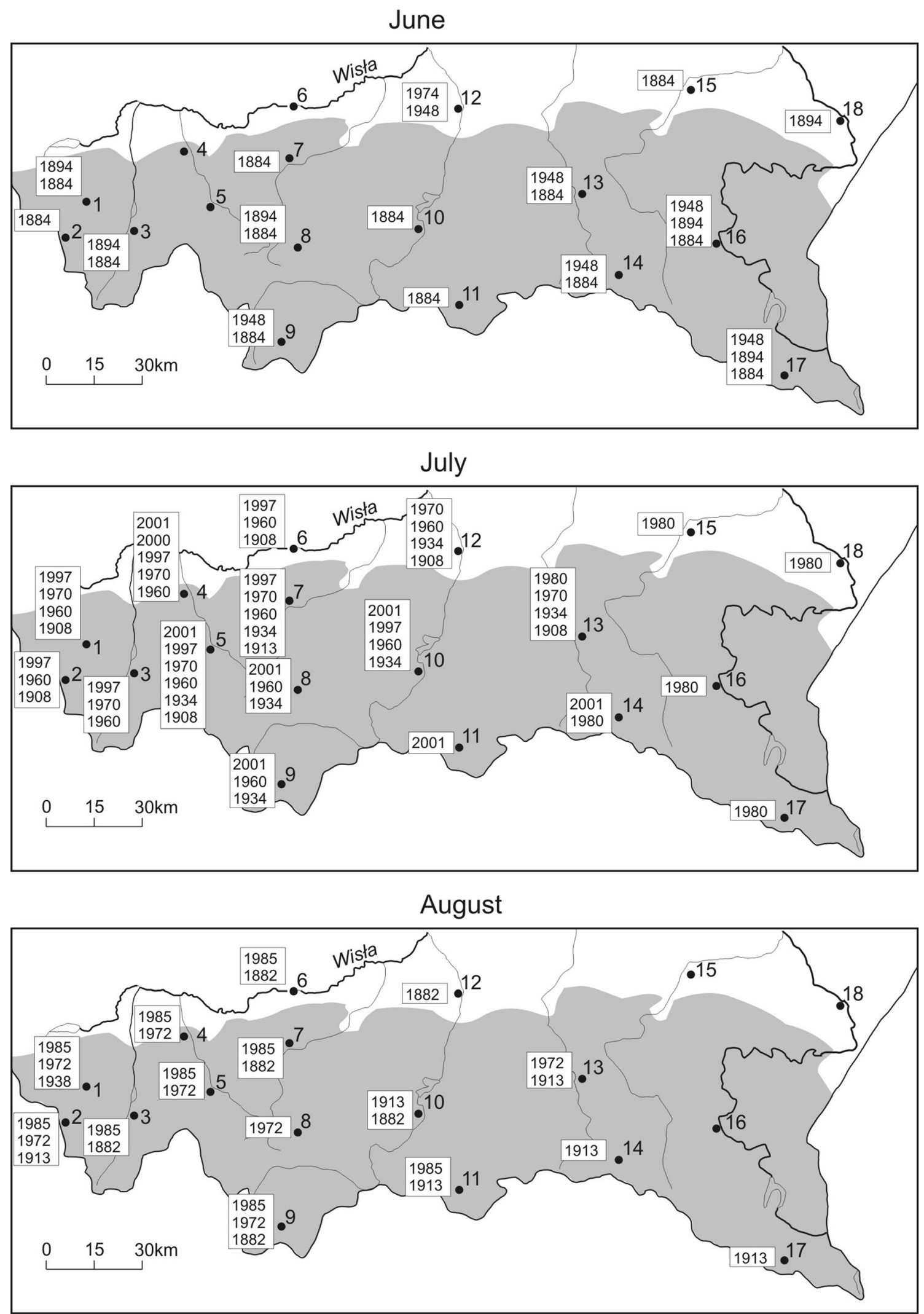

Fig. 5 AHP months in summer

The AHP season of spring 2010 is particularly noteworthy. It covers 12 stations in the western part of the area, including 8 where the precipitation totals were the highest of the study period (Table 8). The totals ranged from $351 \mathrm{~mm}(228 \%)$ in 
Table 10 Number of AHP seasons and AHP years recorded at the same time in station number ranges

\begin{tabular}{|c|c|c|c|c|c|c|c|c|c|c|c|c|c|}
\hline \multirow[t]{2}{*}{ Seasons } & \multicolumn{12}{|c|}{ Number of stations } & \multirow[b]{2}{*}{$\Sigma$} \\
\hline & 1 & 2 & 3 & 4 & 5 & 6 & 7 & 8 & 9 & 10 & 11 & 12 & \\
\hline Spring & 7 & - & 1 & 2 & 3 & 1 & - & - & - & - & - & 1 & 15 \\
\hline Summer & 9 & 2 & 4 & 2 & - & - & - & - & - & - & - & - & 17 \\
\hline Autumn & 4 & 6 & 1 & 3 & 3 & - & - & - & - & - & 2 & - & 19 \\
\hline Winter & 8 & 3 & 1 & 1 & - & - & - & - & - & - & - & - & 13 \\
\hline$\Sigma$ & 28 & 11 & 7 & 8 & 6 & 1 & - & - & - & - & 2 & 1 & 64 \\
\hline Year & 6 & 2 & 1 & 1 & - & - & - & - & - & 1 & - & - & 11 \\
\hline
\end{tabular}

Maximum values in italics

Krakow to $662 \mathrm{~mm}$ in Wisła (247\%), while the greatest relative anomaly of $278 \%$ was recorded in Wadowice $(495 \mathrm{~mm})$. In May of this anomalous season, all 12 stations also recorded AHP that triggered a flood in southern Poland (Maciejowski et al. 2011). This confirms a more general pattern where May was the crucial month contributing to springtime anomalies.
The two largest-scale autumn AHP seasons, in 1931 and 2007 , occurred at 11 stations of the south-western and central part of the area.

The summer and winter seasonal anomalies were relatively small with a maximum of four to five stations in various parts of the study area. The summer AHP seasons were even smaller with two occurrences covering four stations each: an eastern part in 1893 and a western part in 1960. July precipitation contributed most to the summertime AHP seasons.

As has already been mentioned, six of the 11 years with AHP occurred at only a single station (Table 10). A notable exception in this sparse distribution was 2010 where the anomaly was recorded at ten stations scattered across the study area and with a maximum precipitation at each of them. The total precipitation in Krakow $(1126 \mathrm{~mm})$ represented the highest surplus over the average at $177 \%$. This anomaly owed its status not only to springtime precipitation, but also to that of the summer, which, in Krakow, was also an AHP season. The highest absolute precipitation total of this year was recorded in Krynica at $1344 \mathrm{~mm}(156 \%)$.

Table 11 Frequency (\%) of circulation types in southern Poland (Niedźwiedź 1981, 2014)

\begin{tabular}{|c|c|c|c|c|c|c|c|c|c|c|c|c|c|c|}
\hline \multicolumn{2}{|c|}{ Circulation type } & \multirow{2}{*}{$\frac{\text { Jan }}{2.1}$} & \multirow{2}{*}{$\frac{\mathrm{Feb}}{2.9}$} & \multirow{2}{*}{$\begin{array}{l}\text { March } \\
3.0\end{array}$} & \multirow{2}{*}{$\frac{\text { Apr }}{3.1}$} & \multirow{2}{*}{$\frac{\text { May }}{4.7}$} & \multirow{2}{*}{$\frac{\text { Jun }}{5.6}$} & \multirow{2}{*}{$\frac{\text { July }}{5.3}$} & \multirow{2}{*}{$\frac{\text { Aug }}{3.3}$} & \multirow{2}{*}{$\frac{\text { Sep }}{3.2}$} & \multirow{2}{*}{$\frac{\text { Oct }}{2.8}$} & \multirow{2}{*}{$\frac{\text { Nov }}{2.1}$} & \multirow{2}{*}{$\frac{\text { Dec }}{2.2}$} & \multirow{2}{*}{$\frac{\text { Jan-Dec }}{3.4}$} \\
\hline 1 & $\mathrm{Na}$ & & & & & & & & & & & & & \\
\hline 2 & $\mathrm{NEa}$ & 2.2 & 2.6 & 2.9 & 4.1 & 6.4 & 4.6 & 4.7 & 4.4 & 3.2 & 1.9 & 1.6 & 1.7 & 3.4 \\
\hline 3 & $\mathrm{Ea}$ & 6.2 & 6.5 & 7.0 & 6.2 & 8.4 & 4.1 & 3.9 & 4.7 & 4.9 & 5.5 & 4.4 & 5.4 & 5.6 \\
\hline 4 & SEa & 7.2 & 7.8 & 7.2 & 4.7 & 4.2 & 1.9 & 1.2 & 2.8 & 5.2 & 7.3 & 6.5 & 6.5 & 5.2 \\
\hline 5 & $\mathrm{Sa}$ & 3.1 & 3.6 & 3.9 & 2.9 & 2.4 & 1.6 & 1.3 & 2.4 & 4.1 & 5.6 & 5.5 & 3.8 & 3.3 \\
\hline 6 & SWa & 6.0 & 3.8 & 3.3 & 2.7 & 2.0 & 1.9 & 1.7 & 3.2 & 5.2 & 6.9 & 6.9 & 6.1 & 4.2 \\
\hline 7 & Wa & 15.3 & 11.9 & 7.9 & 4.9 & 4.2 & 7.4 & 10.2 & 12.0 & 11.0 & 11.7 & 11.9 & 13.6 & 10.2 \\
\hline 8 & NWa & 5.3 & 5.4 & 5.2 & 3.5 & 3.8 & 6.9 & 7.0 & 6.0 & 6.6 & 4.7 & 4.6 & 4.6 & 5.3 \\
\hline 9 & $\mathrm{Ca}$ & 2.8 & 2.1 & 1.5 & 1.2 & 1.5 & 1.9 & 1.8 & 2.7 & 3.5 & 3.2 & 2.1 & 2.3 & 2.2 \\
\hline 10 & $\mathrm{Ka}$ & 10.0 & 8.7 & 9.3 & 11.8 & 12.4 & 14.5 & 16.2 & 16.3 & 14.4 & 11.4 & 9.9 & 9.5 & 12.0 \\
\hline 11 & $\mathrm{Nc}$ & 1.6 & 2.5 & 2.5 & 3.8 & 3.4 & 4.4 & 4.1 & 2.9 & 2.2 & 1.4 & 1.3 & 1.5 & 2.6 \\
\hline 12 & $\mathrm{NEc}$ & 1.1 & 1.6 & 1.6 & 3.2 & 3.0 & 3.6 & 2.5 & 2.3 & 1.5 & 1.2 & 1.1 & 1.1 & 2.0 \\
\hline 13 & $\mathrm{Ec}$ & 1.8 & 2.3 & 3.1 & 3.9 & 4.1 & 3.0 & 1.2 & 1.0 & 1.6 & 1.9 & 1.8 & 1.8 & 2.3 \\
\hline 14 & $\mathrm{SEc}$ & 2.2 & 3.2 & 3.8 & 4.8 & 3.5 & 2.2 & 1.1 & 1.4 & 1.7 & 1.9 & 3.3 & 2.6 & 2.6 \\
\hline 15 & $\mathrm{Sc}$ & 2.7 & 3.8 & 3.6 & 4.4 & 3.6 & 1.4 & 1.3 & 1.5 & 2.4 & 3.5 & 5.1 & 3.4 & 3.1 \\
\hline 16 & SWc & 5.7 & 6.6 & 6.7 & 5.5 & 4.4 & 2.4 & 2.6 & 2.8 & 3.9 & 6.5 & 7.0 & 6.9 & 5.1 \\
\hline 17 & $\mathrm{Wc}$ & 12.7 & 11.4 & 10.6 & 8.7 & 6.0 & 8.1 & 11.6 & 10.5 & 10.0 & 10.2 & 12.1 & 14.0 & 10.5 \\
\hline 18 & NWc & 5.1 & 4.9 & 5.5 & 5.0 & 4.8 & 7.2 & 7.9 & 5.6 & 4.4 & 3.5 & 4.1 & 4.6 & 5.2 \\
\hline 19 & $\mathrm{Cc}$ & 0.6 & 0.9 & 0.8 & 1.7 & 1.5 & 1.6 & 0.9 & 1.0 & 0.7 & 0.8 & 0.9 & 0.6 & 1.0 \\
\hline 20 & $\mathrm{Bc}$ & 4.5 & 5.7 & 8.4 & 11.9 & 13.9 & 14.1 & 12.3 & 12.0 & 8.4 & 6.6 & 6.4 & 6.0 & 9.2 \\
\hline 21 & $\mathrm{X}$ & 1.6 & 1.8 & 2.0 & 2.0 & 1.8 & 1.5 & 1.0 & 1.5 & 1.8 & 1.7 & 1.5 & 1.6 & 1.7 \\
\hline $1-21$ & Total & 100.0 & 100.0 & 100.0 & 100.0 & 100.0 & 100.0 & 100.0 & 100.0 & 100.0 & 100.0 & 100.0 & 100.0 & 100.0 \\
\hline $1-10$ & $\mathrm{a}$ & 60.2 & 55.3 & 51.3 & 45.0 & 49.9 & 50.5 & 53.4 & 57.7 & 61.3 & 60.7 & 55.5 & 55.8 & 54.7 \\
\hline $11-20$ & $\mathrm{c}$ & 38.1 & 42.9 & 46.6 & 52.9 & 48.3 & 48.0 & 45.6 & 40.8 & 37.0 & 37.6 & 43.0 & 42.6 & 43.6 \\
\hline
\end{tabular}

Maximum values in italics

$a$ anticyclone types, $c$ cyclonic types 
There are only two other AHP years of note. That of 1966 was recorded at four stations in different parts of the area, including Bielsko-Biała with a highest total of $1508 \mathrm{~mm}$ (152\%) and Krakow with the highest surplus of $156 \%$ (1000 mm). In 1939, three stations recorded a year with AHP (AHP year) 'with totals of around $1200 \mathrm{~mm}$.

\section{Atmospheric circulation vs. AHP}

Certain features of atmospheric circulation are regarded among key causes of precipitation. Many other Polish researchers have identified and documented the effect of circulation on high daily precipitation totals in the Carpathian Mountains and their foreland. In general, their findings link this precipitation to cyclonic circulation. In his study, Niedźwiedź et al. (2009) go so far as to conclude that more than $60 \%$ of the variability of precipitation totals in this area can be explained by variability of the cyclonicity index. The authors also demonstrated that macro-scale atmospheric circulation (NAO) had only minor influence on precipitation in
Central Europe that amounted to $4 \%$ of the variance of the annual precipitation and up to ca. $40 \%$ of the variance of winter precipitation.

To determine what circulation conditions lead to the formation of anomalously heavy monthly precipitation, the authors investigated the frequency of circulation types in southern Poland using a calendar proposed by Niedźwiedź (1981, 2014). Discussions of this calendar, which includes 21 circulation types, can be found in numerous studies (e.g. Twardosz 2009; Niedźwiedź et al. 2009).

The study looked at the frequency of circulation types throughout the 130-year study period (Table 11) and in the 212 (Table 2) AHP months (Table 12) and at selected months with AHP recorded at all stations, at stations in the western part and at stations in the eastern part of the area (Table 13). This procedure produced a somewhat simplified picture of the types of circulation conducive to the formation of heavy precipitation. To obtain a full picture, the numbers of days with various ranges of precipitation totals at each station would have to be taken into account to differentiate between cyclonic and convective precipitation types.

Table 12 Frequency (\%) of circulation types in southern Poland during the 212 AHP months (number of calendar months with AHP months as in Table 2)

\begin{tabular}{|c|c|c|c|c|c|c|c|c|c|c|c|c|c|}
\hline \multicolumn{2}{|c|}{ Circulation type } & \multirow{2}{*}{$\frac{\text { Jan }}{1.6}$} & \multirow{2}{*}{$\frac{\text { Feb }}{2.0}$} & \multirow{2}{*}{$\begin{array}{l}\text { March } \\
5.3\end{array}$} & \multirow{2}{*}{$\frac{\text { Apr }}{2.5}$} & \multirow{2}{*}{$\frac{\text { May }}{4.9}$} & \multirow{2}{*}{$\frac{\text { Jun }}{6.5}$} & \multirow{2}{*}{$\frac{\text { July }}{6.1}$} & \multirow{2}{*}{$\frac{\text { Aug }}{4.9}$} & \multirow{2}{*}{$\begin{array}{c}\text { Sep } \\
3.0\end{array}$} & \multirow{2}{*}{$\frac{\text { Oct }}{2.2}$} & \multirow{2}{*}{$\frac{\text { Nov }}{1.1}$} & \multirow{2}{*}{$\frac{\text { Dec }}{2.8}$} \\
\hline 1 & $\mathrm{Na}$ & & & & & & & & & & & & \\
\hline 2 & $\mathrm{NEa}$ & 2.0 & 2.5 & 1.4 & 3.7 & 5.8 & 5.1 & 4.5 & 5.7 & 5.0 & 2.2 & 0.9 & 1.6 \\
\hline 3 & $\mathrm{Ea}$ & 5.8 & 4.5 & 4.4 & 6.7 & 5.6 & 1.7 & 2.0 & 5.1 & 7.0 & 6.7 & 2.0 & 3.0 \\
\hline 4 & $\mathrm{SEa}$ & 7.3 & 5.1 & 4.1 & 2.3 & 3.4 & 1.2 & 0.4 & 2.7 & 5.7 & 5.0 & 4.0 & 2.5 \\
\hline 5 & $\mathrm{Sa}$ & 3.2 & 1.6 & 2.1 & 1.1 & 1.5 & 1.4 & 0.9 & 1.3 & 2.6 & 2.0 & 3.6 & 3.2 \\
\hline 6 & SWa & 3.2 & 0.8 & 3.9 & 1.9 & 1.3 & 1.3 & 1.1 & 2.7 & 4.3 & 5.2 & 3.6 & 4.4 \\
\hline 7 & Wa & 12.7 & 11.7 & 9.9 & 4.7 & 4.3 & 4.8 & 7.7 & 10.1 & 8.0 & 12.2 & 10.2 & 16.1 \\
\hline 8 & NWa & 6.9 & 4.1 & 7.1 & 3.0 & 4.1 & 5.5 & 5.7 & 4.7 & 6.9 & 2.7 & 4.9 & 5.3 \\
\hline 9 & $\mathrm{Ca}$ & 1.2 & 0.8 & 1.2 & 1.1 & 0.4 & 1.9 & 1.3 & 0.9 & 0.7 & 2.2 & 0.9 & 2.5 \\
\hline 10 & $\mathrm{Ka}$ & 7.3 & 6.1 & 6.5 & 10.2 & 12.0 & 12.3 & 13.6 & 12.5 & 9.6 & 7.2 & 8.9 & 6.5 \\
\hline 11 & $\mathrm{Nc}$ & 2.8 & 4.9 & 4.6 & 6.5 & 7.5 & 8.0 & 10.4 & 5.9 & 4.4 & 2.5 & 2.4 & 1.6 \\
\hline 12 & $\mathrm{NEc}$ & 1.2 & 3.1 & 2.1 & 4.6 & 4.9 & 5.7 & 3.4 & 4.6 & 2.6 & 2.7 & 1.6 & 2.1 \\
\hline 13 & $\mathrm{Ec}$ & 1.8 & 2.3 & 2.3 & 3.3 & 4.5 & 3.9 & 0.9 & 0.9 & 2.2 & 3.7 & 2.9 & 1.4 \\
\hline 14 & SEc & 1.2 & 4.1 & 3.2 & 3.2 & 5.8 & 1.6 & 1.6 & 1.9 & 3.1 & 1.5 & 3.8 & 2.3 \\
\hline 15 & $\mathrm{Sc}$ & 1.6 & 4.3 & 4.4 & 4.6 & 3.2 & 1.0 & 1.1 & 1.3 & 2.4 & 3.5 & 5.8 & 6.2 \\
\hline 16 & SWc & 6.3 & 8.4 & 5.3 & 6.3 & 3.4 & 2.8 & 3.0 & 2.1 & 3.7 & 5.5 & 8.0 & 4.1 \\
\hline 17 & Wc & 16.9 & 14.3 & 12.2 & 9.6 & 3.9 & 8.8 & 9.5 & 10.6 & 10.0 & 15.1 & 18.9 & 16.6 \\
\hline 18 & NWc & 9.3 & 8.8 & 8.1 & 5.1 & 5.8 & 8.3 & 9.1 & 6.8 & 5.9 & 4.7 & 5.8 & 8.1 \\
\hline 19 & $\mathrm{Cc}$ & 0.4 & 1.4 & 0.9 & 2.5 & 1.9 & 2.6 & 0.7 & 1.3 & 0.7 & 2.2 & 2.0 & 1.2 \\
\hline 20 & $\mathrm{Bc}$ & 5.0 & 7.4 & 9.4 & 14.9 & 14.0 & 14.9 & 15.1 & 12.7 & 10.7 & 9.4 & 7.1 & 6.7 \\
\hline 21 & $\mathrm{X}$ & 2.2 & 2.0 & 1.6 & 2.5 & 1.5 & 0.7 & 2.0 & 1.1 & 1.3 & 1.5 & 1.8 & 1.8 \\
\hline $1-21$ & Total & 100 & 100 & 100 & 100 & 100 & 100 & 100 & 100 & 100 & 100 & 100 & 100 \\
\hline $01-10$ & $\mathrm{a}$ & 51.2 & 39.1 & 45.9 & 37.0 & 43.4 & 41.7 & 43.2 & 50.9 & 52.8 & 47.6 & 40.0 & 47.9 \\
\hline $11-20$ & $\mathrm{c}$ & 46.6 & 59.0 & 52.5 & 60.5 & 55.1 & 57.5 & 54.8 & 48.0 & 45.9 & 50.9 & 58.2 & 50.2 \\
\hline
\end{tabular}

Maximum values in italics 
Table 13 Frequency (\%) circulation types in southern Poland in selected AHP months

\begin{tabular}{|c|c|c|c|c|c|c|c|c|}
\hline \multicolumn{2}{|c|}{ Circulation type } & \multirow{2}{*}{$\begin{array}{l}\text { Jan } 1976 \\
3.2\end{array}$} & \multirow{2}{*}{$\begin{array}{l}\text { Feb } 1946 \\
3.6\end{array}$} & \multirow{2}{*}{$\begin{array}{l}\text { May } 1940 \\
-\end{array}$} & \multirow{2}{*}{$\begin{array}{l}\text { May } 2010 \\
-\end{array}$} & \multirow{2}{*}{$\begin{array}{l}\text { Jul } 1960 \\
-\end{array}$} & \multirow{2}{*}{$\begin{array}{l}\text { Jul } 1980 \\
-\end{array}$} & \multirow{2}{*}{$\begin{array}{l}\text { Sep } 2007 \\
-\end{array}$} \\
\hline 1 & $\mathrm{Na}$ & & & & & & & \\
\hline 2 & $\mathrm{NEa}$ & 3.2 & - & - & 3.2 & - & - & - \\
\hline 3 & $\mathrm{Ea}$ & - & - & 16.1 & - & - & - & - \\
\hline 4 & SEa & 3.2 & - & 6.5 & - & - & - & - \\
\hline 5 & $\mathrm{Sa}$ & - & - & - & - & 3.2 & - & 3.3 \\
\hline 6 & SWa & - & - & 3.2 & - & - & - & 10.0 \\
\hline 7 & Wa & 3.2 & 17.9 & 3.2 & - & 16.1 & 12.9 & 10.0 \\
\hline 8 & NWa & - & 7.1 & 3.2 & 3.2 & 6.5 & - & 20.0 \\
\hline 9 & $\mathrm{Ca}$ & - & - & - & - & 3.2 & - & - \\
\hline 10 & $\mathrm{Ka}$ & 12.9 & 3.6 & 6.5 & 9.7 & 12.9 & 6.5 & 10.0 \\
\hline 11 & $\mathrm{Nc}$ & 3.2 & 7.1 & 6.5 & 16.1 & 16.1 & 9.7 & 3.3 \\
\hline 12 & $\mathrm{NEc}$ & 3.2 & - & 6.5 & 12.9 & 3.2 & 6.5 & 3.3 \\
\hline 13 & $\mathrm{Ec}$ & 3.2 & - & 19.4 & 3.2 & - & 6.5 & - \\
\hline 14 & $\mathrm{SEc}$ & - & - & 9.7 & 3.2 & - & - & 3.3 \\
\hline 15 & $\mathrm{Sc}$ & - & - & - & 9.7 & 3.2 & 3.2 & 3.3 \\
\hline 16 & SWc & - & 7.1 & - & - & - & 9.7 & 3.3 \\
\hline 17 & Wc & 29.0 & 32.1 & - & - & 6.5 & 16.1 & 6.7 \\
\hline 18 & NWc & 19.4 & 14.3 & 6.5 & 12.9 & 3.2 & 3.2 & 10.0 \\
\hline 19 & $\mathrm{Cc}$ & - & - & - & - & - & - & - \\
\hline 20 & $\mathrm{Bc}$ & 9.7 & 7.1 & 12.9 & 25.8 & 12.9 & 22.6 & 13.3 \\
\hline 21 & $X$ & 6.5 & - & - & - & 12.9 & 3.2 & - \\
\hline $1-21$ & Total & 100.0 & 100.0 & 100.0 & 100.0 & 100.0 & 100.0 & 100.0 \\
\hline $01-10$ & $\mathrm{a}$ & 25.8 & 32.1 & 38.7 & 16.1 & 41.9 & 19.4 & 53.3 \\
\hline $11-20$ & $\mathrm{c}$ & 67.7 & 67.9 & 61.3 & 83.9 & 45.2 & 77.4 & 46.7 \\
\hline
\end{tabular}

A certain predominance towards anticyclonic circulation (55\%) is a typical feature of the atmospheric circulation variability over southern Poland (Table 11). Cyclonic circulation prevailed only in April (53\%). As was expected, cyclonic circulation was found to favour the occurrence of AHP months. It is important to point out here that it was not a case of an absolute prevalence of cyclonic circulation types, but their above-average frequency during AHP months. The greatest frequency of cyclonic types during AHP months was found in April at $60 \%$, which is $8 \%$ more than the average. The greatest difference than the two frequencies was found in February at $16 \%$ (with $43 \%$, on average, and $59 \%$ in an AHP months) and in November at $15 \%$ (43 and $58 \%$ ).

Generally, the type of circulation, i.e. cyclonic vs. anticyclonic, has a stronger impact on the formation of an AHP than the direction of air advection. In all AHP months, there occurred one of the most frequent circulation types, i.e. western cyclonic circulation $(\mathrm{Wc})$ or cyclonic trough $(\mathrm{Bc})$. Between October and March, western cyclonic type prevails ranging from $12 \%$ in March (compared to the average of $10.6 \%$ ) to $19 \%$ in November $(12.1 \%)$. Other cyclonic types of the western sector, SWc and NWc (combined 9-17\%), and the Wa type (10-16\%) also played a considerable role. In winter, especially in January, the mid-latitude frontal disturbances have a tendency to converge over Poland producing higher precipitation totals in western advection than with other sectors (Twardosz 2009). For the rest of the year, the cyclonic trough $\mathrm{Bc}$ is more frequent, at $11-15 \%$, on average, followed in frequency by high-pressure wedge $\mathrm{Ka}$, at 10-14\%. Cyclonic trough was found to be most conducive to AHP months in the eastern part of the area; e.g. in July 1980, its frequency was $23 \%$ or twice as high as the average of this month (Table 13). In summer AHP months, northern sector circulation was also more frequent, especially in the western part of the area. For example, in July 1960, the frequency of just one of the types in this sector, Nc, was four times higher than the average (Table 13). These circulation types were conducive to heavy and lasting precipitation, primarily in cold or stationary front zones (Twardosz 2009). Similar patterns of circulation influence causing heavy precipitation were identified in other areas of the country (Kossowska-Cezak 1997). The same circulation types accompanied nearly all days with precipitation in Krakow during AHP of May of 2010 (Woźniak 2012). High monthly precipitation totals in southern Poland can also coincide with anticyclonic circulation types, especially the anticyclonic wedge Ka (Twardosz 2009). In summer, local downpours can form in uniform air masses as a result of strong thermal convection. 
In May 2010, anomalously high precipitation totals in the entire Polish Carpathian Mountains were accompanied primarily by cyclonic trough $(\mathrm{Bc})$ and northern circulation, both twice as frequent as the average (Table 13). The AHP of May 1940 also covered the entire area, but the totals were lower. Eastern circulation, mainly cyclonic, dominated for more than one third of that month (Table 13).

\section{Conclusion}

The study identified anomalously heavy precipitation (AHP) at 18 stations in the Polish Carpathian Mountains and their foreland over a 130-year period spanning 1881-2010. A rather stringent statistical criterion was used as a cut-off at the upper quartile value plus $1.5 \times$ of the interquartile gap.

It was demonstrated that while AHP occurred in all months, in seasons and in entire years, they were also infrequent. There were between one monthly AHP (months with anomalously heavy precipitation, AHP months) per 5 years in June to one AHP month per 10 years in October and between one AHP season (season with AHP) per 7 years in autumn to one AHP season in 10 years in winter.

Most AHP was spatially limited to one or two stations, typically neighbouring ones, thus clearly suggesting that local conditions, as well as circulation-related factors, influenced their occurrence.

AHP recorded in May had the largest area coverage with an average of five stations, while those recorded in November were the smallest at two stations on average.

Two AHP months were recorded at all 18 stations: in May 1940 and May 2010. Both triggered catastrophic floods. The event of 2010 involved both the highest absolute precipitation totals of more than $500 \mathrm{~mm}$ in the western part of the area and the highest relative values, i.e. surplus over the longterm average. In 1940, the highest relative anomaly was recorded in Bielsko-Biała (487 \%). Other large-scale AHP months (15-17 stations) were recorded in September 2007, January 1976, February 1946 and May 1939.

Cyclonic circulation, as expected, prevailed in months with AHP. Between October and March, western sector circulation types prevailed, especially the western cyclonic type (Wc), while, for the rest of the year, it was the cyclonic trough (Bc) followed by an anticyclonic wedge (Ka). These opposite circulation types point to the alternative origins of AHP: either on active atmospheric fronts or on convective types.

In terms of the hydrological and geomorphological effects of AHP, the least dangerous are the AHPs recorded in winter which may have similar surplus values to those occurring in other seasons but feature the lowest totals of all, are the least frequent and cover the smallest areas at a time (one to two stations). This effect is explained by the annual precipitation cycle, which reaches its lowest point in winter. Summer AHP events also covered small areas (no more than four stations), due to the local nature of rainfall of convectional origin, but are more frequent than in winter and feature the highest rainfall totals (up to $600-800 \mathrm{~mm}$ ). AHP in spring and autumn covers the largest areas (11-12 stations).

Generally, AHP was demonstrated to be a rare and spatially limited phenomenon. Indeed, during the 130 years of the study period, there were no AHP seasons that would cover all of the stations in a single season. They were overwhelmingly up to one third of the stations $(6 / 18)$.

The results of the study have a potential practical application due to the information on the frequency, scale and spatial coverage of AHP in various seasons in southern Poland, a region characterised by average precipitation higher than anywhere else in the country (except the Sudety Mountains) and which may lead to dangerous hydrological or geomorphological events, such as floods and landslides.

Acknowledgments We thank Mr. Paweł Pilch and Dr. Martin Cahn for reviewing the English.

Open Access This article is distributed under the terms of the Creative Commons Attribution 4.0 International License (http:// creativecommons.org/licenses/by/4.0/), which permits unrestricted use, distribution, and reproduction in any medium, provided you give appropriate credit to the original author(s) and the source, provide a link to the Creative Commons license, and indicate if changes were made.

\section{References}

Alexandersson $\mathrm{H}$ (1986) A homogeneity test applied to precipitation data. Int J Climatol 6:661-675

Benestad RE (2005) Can we expect more extreme precipitation on the monthly time scale? J Clim 19:630-637

Christensen JH, Christensen OB (2003) Severe summertime flooding in Europe. Nature 421:805-806

Hellmann G (1906) Die Niederschläge in den Norddeutschen Stromgebieten, Zweiter Band, Tabellen I. Dietrich Reimer, Berlin

International Meteorological Vocabulary (1992) WMO, No. 182, Geneva

IPCC (2013) Summary for policymakers. In: Climate change 2013: the physical science basis. Contribution of Working Group I to the Fifth Assessment Report of the Intergovernmental Panel on Climate Change [Stocker, T.F., D. Qin, G.-K. Plattner, M. Tignor, S.K. Allen, J. Boschung, A. Nauels, Y. Xia, V. Bex

Kossowska-Cezak U (1997) Monthly thermal and precipitation conditions and their dependence on atmospheric circulation. Prace i Studia Geograficzne 20:125-144 (in Polish)

Łupikasza E (2010) Spatial and temporal variability of extreme precipitation in Poland in the period 1951-2006. Int J Climatol 30: 991-1007

Maciejowski M, Ostojski M, Walczykiewicz T (eds) (2011) The Vistula river basin: a study of the May-June 2010 flood. Instytut Meteorologii i Gospodarki Wodnej-Państwowy Instytut Badawczy, Warszawa (in Polish)

Miętus M, Filipiak J, Owczarek M, Jakusik E (2005) Variability of precipitation conditions along the Polish Baltic coast in the light of a quartile precipitation classification system. Materiały Badawcze IMGW, s. Meteorologia, 37 (in Polish) 
Niedźwiedź T (1981) Synoptic situations and its influence on spatial differentiation of selected climatic elements in upper Vistula basin. Rozprawy Habilitacyjne UJ, 58 (in Polish)

Niedźwiedź T (2014) Calendar of circulation types, air masses and fronts for Southern Poland. Computer file available at the Department of Climatology, University of Silesia. http://klimat.wnoz.us.edu.pl/

Niedźwiedź T, Obrębska-Starklowa B (1991) Climate. [in.] I. Dynowska, M. Maciejowski (eds), Upper Vistula basin. Wydawnictwo PWN, 68-84 (in Polish)

Niedźwiedź T, Twardosz R, Walanus A (2009) Long-term variability of precipitation series in east central Europe in relation to circulation patterns. Theor Appl Climatol 98:337-350

Palmer TN, Räisänen J (2002) Quantifying the risk of extreme seasonal precipitation events in a changing climate. Nature 415:512-514

Räisänen J (2005) Impact of increasing $\mathrm{CO}_{2}$ on monthly-to-annual precipitation extremes: analysis of the CMIP2 experiments. Clim Dyn 24:309-323

Schönwiese CD, Grieser J, Trömel S (2003) Secular change of extreme monthly precipitation in Europe. Theor Appl Climatol 75:245-250
STATISTICA (data analysis software system), 2010, version 6. StatSoft, Inc. www.statsoft.com

Stedinger JR, Vogel RM, Foufoula-Georgiou E (1993) Frequency analysis of extreme events. In: Maidment DR (ed) Handbook of hydrology. McGraw-Hill, New York, pp 1810-1823

Trömel S, Schönwiese CD (2007) Probability change of extreme precipitation observed from 1901 to 2000 in Germany. Theor Appl Climatol 87:29-39

Twardosz R (2009) Analysis of hourly precipitation characteristics in Kraków, southern Poland, using a classification of circulation types. Hydrol Res 40:553-563

Twardosz R, Kossowska-Cezak U (2015) Extremely cold summers months in Central and Eastern Europe, 1951-2010. Nat Hazard 75: 2013-2026

Woźniak A (2012) Precipitation in 2010 in Cracow on the background of multi-year 1863-2010. Przegląd Geofizyczny 3-4:406-419 (in Polish)

Woźniak A (2013) Precipitation in the Polish Carpathian Mountains in 2010 compared to the period 1881-2010. Prace Geograficzne 133: 35-48 (in Polish) 